\title{
Analysis of Hot Metal Desiliconization Behavior in Converter Experiments by Coupled Reaction Model
}

\author{
Minoru ISHIKAWA
}

Corporate Research \& Development Laboratories, Sumitomo Metal Industries, Ltd., Sunayama, Hasaki-Machi, Kashima-Gun, Ibaraki-Pref. 314-0255 Japan.

(Received on March 31, 2003; accepted in final form on September 24, 2003)

\begin{abstract}
The data in the hot metal desiliconization experiments were analyzed using the coupled reaction model and the reaction mechanisms were investigated. Desiliconization reaction is controlled by the mass transfer in the metal when $(\mathrm{FeO})$ in slag is larger than $35 \mathrm{mass} \%$. Higher ( $\mathrm{FeO}$ ) and agitation energy cause larger apparent volumetric rate constant $V_{\mathrm{Si}}$. This seems to be a result of enhanced mass transfer in metal and slag caused by stronger agitation, enhanced mass transfer in slag caused by higher (FeO) content in slag and larger driving force caused by higher oxygen activity at the slag/metal interface. Strong agitation and low (FeO) content in slag are effective for preferable desiliconization reaction with suppressing the decarburization reaction.
\end{abstract}

KEY WORDS: hot metal treatment; desiliconization; coupled reaction model; mass transfer; agitation energy; apparent volumetric rate constant.

\section{Introduction}

Recently, desiliconization process is again interested in by increasing demands for decreasing the amount of slag generated in the process of hot metal dephosphorization. Several studies ${ }^{1-4)}$ have been made for this process and commercial operations have been made today. Ohguchi et $a l .{ }^{5)}$ and Mukawa et $a l .{ }^{6)}$ reported the analysis of hot metal dephosphrization reaction using the coupled reaction model. Shibata et ll. $^{3)}$ also reported the analysis of hot metal desiliconization reaction using the coupled reaction model. However, no information is available concerning the effect of stirring energy and the role of $\left(\mathrm{Fe}_{2} \mathrm{O}_{3}\right)$ included in the desiliconization agent which have important role in the commercial desiliconization operation.

In this study, the coupled reaction model was developed. By the model, it is possible to predict the behavior of each element in the desiliconization experiments considering not only $\mathrm{FeO}$ but also $\mathrm{Fe}_{2} \mathrm{O}_{3}$ and $\mathrm{MnO}$ as oxidizer. The data in the desiliconization experiments were analyzed using the model and the reaction mechanisms were considered.

\section{Experimental Method}

Experimental procedure is shown in Fig. 1. Desiliconization experiments were done in the test converter shown in Fig. 2. Sintered ore with chemical composition shown in Table 1 was used as desiliconization agent which is generally used in the commercial desiliconization operation. The sintered ore included not only $\mathrm{FeO}$ which was generally used as desiliconization agent in laboratory experiments but also $\mathrm{Fe}_{2} \mathrm{O}_{3}$. Experimental condition is shown in Table 2. In Table 2, initial [Si] content in pig iron used for coupled reaction model calculation was set as analyzed [Si] content in metal sample taken at the same time as the first slag sample in each experiment. The first metal sample was taken just before the start of oxygen blowing, but the first slag sample was taken at several minutes after the start of the blowing. Therefore, initial [Si] content in pig iron used for coupled reaction model calculation was ranged in 0.19 to $0.32 \%$ which was lower than that of initial pig iron as shown in Table 2. In order to keep hot metal temperature constant during the experiment, a small amount of oxygen was blown into the hot metal through the top blowing lance.

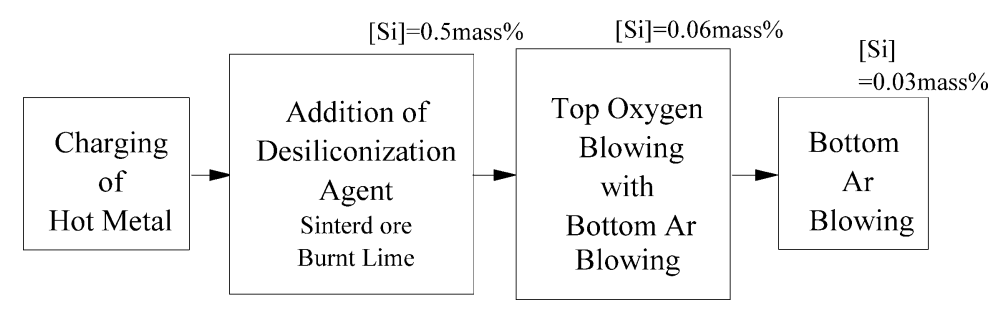

Fig. 1. Experimental procedure. 


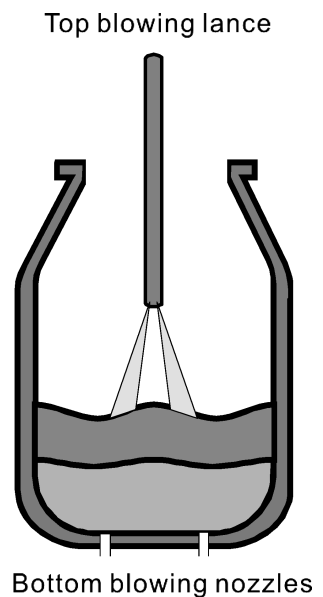

Fig. 2. Top and bottom blowing test converter used in experiments.

Table 1. Composition of sintered ore and grain size.

\begin{tabular}{|c|c|c|c|c|c|c|c|c|c|}
\hline \multirow{2}{*}{$\begin{array}{l}\text { TEST } \\
\text { No. }\end{array}$} & \multicolumn{8}{|c|}{ Composition (mass\%) } & \multirow{2}{*}{$\begin{array}{c}\text { Grain } \\
\text { size }(\mathrm{mm})\end{array}$} \\
\hline & $\mathrm{CaO}$ & $\mathrm{SiO}_{2}$ & $\mathrm{Al}_{2} \mathrm{O}_{3}$ & $\mathrm{MgO}$ & T.Fe & $\mathrm{FeO}$ & M.Fe & $\mathrm{S}$ & \\
\hline TEST-1 & 10.1 & 4.4 & 1.2 & 1.5 & 59.1 & 1.4 & 0.3 & 0.01 & $10 / 25$ \\
\hline $\begin{array}{l}\text { TEST } \\
-2 \sim 4\end{array}$ & 10.3 & 5.9 & 2.1 & 1.5 & 58.0 & 7.0 & 0.3 & 0.01 & $1.0 / 2.0$ \\
\hline
\end{tabular}

Table 2. Experimental conditions.

\begin{tabular}{|c|c|c|c|c|c|c|}
\hline & TEST-1 & TEST-2 & TEST-3 & TEST-4 \\
\hline \multirow{5}{*}{$\begin{array}{l}\text { Pig } \\
\text { iron }\end{array}$} & \multicolumn{2}{|c|}{ Amount $(t)$} & \multicolumn{4}{|c|}{2.0} \\
\hline & \multirow[t]{2}{*}{ Initial } & $\begin{array}{l}{[\% \mathrm{Si}]} \\
\text { (ForCalc.) }\end{array}$ & $\begin{array}{c}0.50 \\
(0.19)\end{array}$ & $\begin{array}{c}0.55 \\
(0.32)\end{array}$ & $\begin{array}{r}0.56 \\
(0.29)\end{array}$ & $\begin{array}{c}0.63 \\
(0.31)\end{array}$ \\
\hline & & Temperature $\left({ }^{\mathrm{C}} \mathrm{C}\right)$ & 1326 & 1336 & 1355 & 1324 \\
\hline & \multirow[t]{2}{*}{ Final } & {$[\% \mathrm{Si}]$} & 0.02 & 0.08 & 0.06 & 0.05 \\
\hline & & Temperature $\left({ }^{\circ} \mathrm{C}\right)$ & 1357 & 1394 & 1405 & 1378 \\
\hline \multirow[t]{2}{*}{$\begin{array}{l}\text { De-Si } \\
\text { agent }\end{array}$} & \multicolumn{2}{|c|}{$\begin{array}{l}\text { Sinter ore(kg) } \\
\text { (Grain size) }\end{array}$} & $\begin{array}{c}35 \\
(15 / 25 \mathrm{~mm})\end{array}$ & \multicolumn{3}{|c|}{$\begin{array}{c}60 \\
(1.0 / 2.0 \mathrm{~mm}) \\
\end{array}$} \\
\hline & \multicolumn{2}{|c|}{ Burnt lime $(\mathrm{kg})$} & 1.5 & \multicolumn{3}{|c|}{$2.4 \sim 6.4$} \\
\hline \multirow[t]{3}{*}{ Gas } & \multicolumn{2}{|c|}{$\begin{array}{l}\mathrm{Top}_{2}\left(\mathrm{Nm}^{3} / \mathrm{min} .\right) \\
\times \text { time (min.) }\end{array}$} & $3.0 \times 3.25$ & $\begin{array}{l}3.4 \times 3.45 \\
+1.0 \times 2.6\end{array}$ & $\begin{array}{c}3.4 \times 3.2 \\
+1.0 \times 2.8\end{array}$ & $1.5 \times 11.0$ \\
\hline & \multicolumn{2}{|c|}{ Top blowing lance height } & \multicolumn{4}{|c|}{$0.60 \mathrm{~m}$} \\
\hline & \multicolumn{2}{|c|}{$\begin{array}{l}\text { Bottom } \mathrm{Ar}\left(\mathrm{Nm}^{3} / \mathrm{min} .\right) \\
\text { (Agitation energy) }\end{array}$} & $\begin{array}{c}0.6 \\
(820 \mathrm{~J} / \mathrm{s} \cdot \mathrm{t})\end{array}$ & $\begin{array}{c}0.2 \\
(270 \mathrm{~J} / \mathrm{s} \cdot \mathrm{t})\end{array}$ & $\begin{array}{c}0.2 \\
(270 \mathrm{~J} / \mathrm{s} \cdot \mathrm{t})\end{array}$ & $\begin{array}{c}0.18 \\
(260 \mathrm{~J} / \mathrm{s} \cdot \mathrm{t})\end{array}$ \\
\hline
\end{tabular}

However, soft blowing was done during experiments for suppressing a direct reaction of oxygen gas with elements in hot metal. Agitation power of bottom blowing was controlled in two levels of $820 \mathrm{~J} /(\mathrm{s} \cdot \mathrm{t})$ and 260 to $270 \mathrm{~J} /(\mathrm{s} \cdot \mathrm{t})$. By changing the amount of sintered ore addition and oxygen blowing pattern, $(\mathrm{FeO})$ and $\left(\mathrm{Fe}_{2} \mathrm{O}_{3}\right)$ contents in slag were controlled in 4 experiments.

\section{Coupled Reaction Model}

In the Coupled Reaction Model developed in this study, not only $\mathrm{FeO}$ which was considered in the model reported before ${ }^{3)}$ but also $\mathrm{Fe}_{2} \mathrm{O}_{3}$ and $\mathrm{MnO}$ were considered as oxidizer. Top blowing oxygen was also considered to react with iron in hot metal and $\mathrm{FeO}$ in slag. Carbon and silicon in hot metal were considered not to react directory with top blowing oxygen but to react with $\mathrm{FeO}$ and $\mathrm{Fe}_{2} \mathrm{O}_{3}$ in slag due to decarburization and desiliconization behaviors mentioned later.

Decarburization, desiliconization, oxidation of manganese and phosphorous, transport of oxygen in hot metal and iron oxide in slag were considered in this study. Desulphurization was not considered because sulfur content of hot metal was low $(0.003$ to $0.004 \%)$ and it did not change during the test. The same rate equations of decarburization, desiliconization, oxidation of manganese and phosphorous, transport of oxygen in hot metal and $\mathrm{FeO}$ in slag were used in the previously reported model. ${ }^{3)}$

Desiliconization, oxdation of manganese and dephosphorization are considered to be controlled by mass transfer in hot metal and slag. The rate equations of these reactions are given as follows.

$$
\begin{gathered}
-\frac{d[\% \mathrm{Si}]}{d t}=\frac{A k_{\mathrm{Si}}}{W_{\mathrm{m}}}\left\{[\% \mathrm{Si}] L_{\mathrm{Si}}^{*}-(\% \mathrm{Si})\right\} \ldots . . . \\
-\frac{d[\% \mathrm{Mn}]}{d t}=\frac{A k_{\mathrm{Mn}}}{W_{\mathrm{m}}}\left\{[\% \mathrm{Mn}] L_{\mathrm{Mn}}^{*}-(\% \mathrm{Mn})\right\} \\
-\frac{d[\% \mathrm{P}]}{d t}=\frac{A k_{\mathrm{P}}}{W_{\mathrm{m}}}\left\{[\% \mathrm{P}] L_{\mathrm{P}}^{*}-(\% \mathrm{P})\right\} \ldots \ldots . . . . . . .
\end{gathered}
$$

where,

$k_{\mathrm{Si}}, k_{\mathrm{Mn}}, k_{\mathrm{P}}$ : over all mass transfer coefficient $\left(\mathrm{kg} / \mathrm{m}^{2} \cdot \mathrm{s}\right)$ $L_{\mathrm{Si}}^{*}, L_{\mathrm{Mn}}^{*}, L_{\mathrm{P}}^{*}$ : distribution ratio of each elements between slag and metal at slag and metal interface

$A: \quad$ interfacial area $\left(\mathrm{m}^{2}\right)$

$W_{\mathrm{m}}$ : amount of the hot metal $(\mathrm{kg})$

Final slag basicity varied from 0.28 to 0.42 in the experiments of this work. As the slag basicity affects desiliconization reaction rate by changing distribution ratio, distribution ratio of silicon between slag and metal at slag-metal interface was calculated considering slag composition including $(\mathrm{CaO})$ and $\left(\mathrm{SiO}_{2}\right)$ contents as will be mentioned later in appendix. Also as overall mass transfer coefficient of silicon reaction is affected by slag basicity by changing slag fluidity, that was treated as parameter decided by fitting.

Decarburization reaction is considered not to be controlled by mass transfer of carbon in the hot metal but to be controlled by the chemical reaction and oxygen transfer in the hot metal. The rate equation is given by Eq. (4):

$$
-\frac{d[\% \mathrm{C}]}{d t}=\frac{A k_{\mathrm{C}}}{W_{\mathrm{m}}}\left\{f_{\mathrm{C}}[\% \mathrm{C}] a_{\mathrm{O}}^{*}-P_{\mathrm{CO}}^{*} / K_{\mathrm{C}}\right\}
$$

where,

$k_{\mathrm{C}}$ : chemical reaction rate constant of decarburization $\left(\mathrm{kg} / \mathrm{m}^{2} \cdot \mathrm{s}\right)$

$f_{\mathrm{C}}$ : activity coefficient of Carbon in Henry standard

$a_{0}^{*}$ : oxygen activity at slag and metal interface

$P_{\mathrm{CO}}^{*}$ : partial pressure of $\mathrm{CO}$ at slag and metal interface

$K_{\mathrm{C}}$ : equilibrium constant of $\mathrm{C}-\mathrm{O}$ reaction in metal

Oxygen reaction in the metal is considered to be controlled by the mass transfer of oxygen in the hot metal and slag. The rate equation is given by Eq. (5):

$$
-\frac{d[\% \mathrm{O}]}{d t}=\frac{A k_{\mathrm{m}} \rho_{\mathrm{m}}}{W_{\mathrm{m}}}\left\{[\% \mathrm{O}]-a_{\mathrm{O}}^{*} / f_{\mathrm{O}}\right\}
$$


where,

$k_{\mathrm{m}}$ : mass transfer coefficient in the hot metal $(\mathrm{m} / \mathrm{s})$

$\rho_{\mathrm{m}}$ : density of the hot metal $\left(\mathrm{kg} / \mathrm{m}^{3}\right)$

$f_{\mathrm{O}}$ : activity of oxygen in Henrian standard

Not only $\mathrm{FeO}$ which was taken into account in the previous works but also $\mathrm{Fe}_{2} \mathrm{O}_{3}$ are taken into account as iron oxide in this work. $\mathrm{FeO}$ reaction in the slag is considered to be controlled by the mass transfer of $\mathrm{FeO}$ in the slag according to Shibata et al. ${ }^{3)}$ The rate equation is given by Eq. (6):

$$
-\frac{d \%(\mathrm{FeO})}{d t}=\frac{A k_{\mathrm{s}} \rho_{\mathrm{s}}}{W_{\mathrm{s}}}\left\{(\% \mathrm{FeO})-L_{\mathrm{O}}^{*} a_{\mathrm{O}}^{*}\right\}
$$

where,

$k_{\mathrm{s}}:$ mass transfer coefficient in the slag $(\mathrm{m} / \mathrm{s})$

$\rho_{\mathrm{s}}:$ density of the slag $\left(\mathrm{kg} / \mathrm{m}^{3}\right)$

$W_{\mathrm{s}}$ : weight of the slag $(\mathrm{kg})$

On the other hand, the rate of $\mathrm{Fe}_{2} \mathrm{O}_{3}$ reaction:

$$
\left(\mathrm{Fe}_{2} \mathrm{O}_{3}\right)=2(\mathrm{FeO})+[\mathrm{O}]
$$

is considered to be expressed by Eq. (8) considering the distribution ratio between oxygen in the metal and $\mathrm{Fe}_{2} \mathrm{O}_{3}$ in the slag $\left(L_{\mathrm{O}}^{*}\right)_{2}$ :

$$
-\frac{d \%\left(\mathrm{Fe}_{2} \mathrm{O}_{3}\right)}{d t}=\frac{A k_{\mathrm{s}} \rho_{\mathrm{s}}}{W_{\mathrm{s}}}\left\{\left(\% \mathrm{Fe}_{2} \mathrm{O}_{3}\right)-\left(L_{\mathrm{O}}^{*}\right)_{2} a_{\mathrm{O}}^{*}\right\}
$$

Also as a reaction of manganese, Eq. (9) is considered.

$$
(\mathrm{MnO})=[\mathrm{Mn}]+[\mathrm{O}]
$$

The rate of above reaction is given by Eq. (10) considering the distribution ratio of $\mathrm{MnO}$ and oxygen in the slag and metal interface $L_{\mathrm{Mn}}^{*}$.

$$
-\frac{d \%(\mathrm{MnO})}{d t}=\frac{A k_{\mathrm{s}} \rho_{\mathrm{s}}}{W_{\mathrm{s}}}\left\{(\% \mathrm{MnO})-\frac{70.9}{54.9} \cdot L_{\mathrm{Mn}}^{*}[\% \mathrm{Mn}]\right\}
$$

Overall mass transfer coefficients of silicon, manganese and phosphorous are given by Eqs. (11), (12) and (13) respectively:

$$
\begin{aligned}
& \frac{1}{k_{\mathrm{Si}}}=\frac{L_{\mathrm{Si}}^{*}}{k_{\mathrm{m}} \rho_{\mathrm{m}}}+\frac{1}{k_{\mathrm{s}} \rho_{\mathrm{s}}} \\
& \frac{1}{k_{\mathrm{Mn}}}=\frac{L_{\mathrm{Mn}}^{*}}{k_{\mathrm{m}} \rho_{\mathrm{m}}}+\frac{1}{k_{\mathrm{s}} \rho_{\mathrm{s}}} \\
& \frac{1}{k_{\mathrm{P}}}=\frac{L_{\mathrm{P}}^{*}}{k_{\mathrm{m}} \rho_{\mathrm{m}}}+\frac{1}{k_{\mathrm{s}} \rho_{\mathrm{s}}}
\end{aligned}
$$

Also, distribution ratios of each element between slag and metal are given by Eqs. (14)-(18):

$$
\begin{gathered}
L_{\mathrm{Si}}^{*}=\frac{(\% \mathrm{Si})^{*}}{[\% \mathrm{Si}]^{*}}=B_{\mathrm{Si}} a_{\mathrm{O}}^{* 2} \\
L_{\mathrm{Mn}}^{*}=\frac{(\% \mathrm{Mn})^{*}}{[\% \mathrm{Mn}]^{*}}=B_{\mathrm{Mn}} a_{\mathrm{O}}^{*}
\end{gathered}
$$

$$
\begin{gathered}
L_{\mathrm{P}}^{*}=\frac{(\% \mathrm{P})^{*}}{[\% \mathrm{P}]^{*}}=B_{\mathrm{P}} a_{\mathrm{O}}^{* 2.5} \\
L_{\mathrm{O}}^{*}=\frac{(\% \mathrm{FeO})^{*}}{a_{\mathrm{O}}^{*}} \ldots . . \\
\left(L_{\mathrm{O}}^{*}\right)_{2}=\frac{\left(\% \mathrm{Fe}_{2} \mathrm{O}_{3}\right)^{*}}{a_{\mathrm{O}}^{*}} .
\end{gathered}
$$

$B_{\mathrm{S}}^{*}, B_{\mathrm{Mn}}^{*}$ and $B_{\mathrm{P}}^{*}$ are the apparent equilibrium constants of each element and are given by Eqs. (19)-(21):

$$
\begin{aligned}
B_{\mathrm{Si}}^{*} & =\frac{K_{\mathrm{Si}} M_{\mathrm{Si}} f_{\mathrm{Si}} \sum N_{M O_{x}}}{\gamma_{\mathrm{SiO}_{2}}} \ldots \\
B_{\mathrm{Mn}}^{*} & =\frac{K_{\mathrm{Mn}} M_{\mathrm{Mn}} f_{\mathrm{Mn}} \sum N_{M O_{x}}}{\gamma_{\mathrm{MnO}}} \\
B_{\mathrm{P}}^{*} & =\frac{K_{\mathrm{P}} M_{\mathrm{P}} f_{\mathrm{P}} \sum N_{M O_{x}}}{\gamma_{\mathrm{PO}_{2.5}}} \ldots
\end{aligned}
$$

where,

$K_{\mathrm{Si}}$ : equilibrium constant $\left(\mathrm{Si}+2 \mathrm{O}=\mathrm{SiO}_{2}\right.$ (R.S.), R.S.: Regular solution)

$\ln K_{\mathrm{Si}}=\ln \left(a_{\mathrm{SiO}_{2}} / a_{\mathrm{Si}} a_{\mathrm{O}}^{2}\right)=66083 / T-26.5$

$M$ : molecular weight

$f$ : activity coefficient in Henrian standard

$\Sigma N_{M O x}:$ molecular number of all elements in slag (mol/100 g-slag)

In this work, $B_{\mathrm{Si}}^{*}$ was calculated by Eq. (19) by using $\gamma_{\mathrm{SiO}_{2}}$ derived from regular solution model. ${ }^{13)}$ In Eq. (19), conversion factor for the reference state of the activities between regular and real solutions is not considered, but estimation error by that is clarified to be negligibly small. On the other hand, $B_{\mathrm{Mn}}^{*}, B_{\mathrm{P}}^{*}, L_{\mathrm{O}}^{*}$ and $\left(L_{\mathrm{O}}^{*}\right)_{2}$ were treated as parameters and were determined to fit calculations with experimental results. Calculation method of $\gamma_{\mathrm{SiO}_{2}}$ is shown in Appendix.

From the oxygen balance in slag-metal interface given by Eq. (22), oxygen activity at the interface is calculated.

$$
\begin{aligned}
\frac{W_{\mathrm{m}}}{M_{\mathrm{C}}} & \frac{d[\% \mathrm{C}]}{d t}+\frac{2 W_{\mathrm{m}}}{M_{\mathrm{Si}}} \frac{d[\% \mathrm{Si}]}{d t} \\
& +\frac{2 W_{\mathrm{m}}}{M_{\mathrm{Mn}}} \frac{d[\% \mathrm{Mn}]}{d t}+\frac{2.5 W_{\mathrm{m}}}{M_{\mathrm{P}}} \frac{d[\% \mathrm{P}]}{d t} \\
= & \frac{W_{\mathrm{m}}}{M_{\mathrm{O}}} \frac{d[\% \mathrm{O}]}{d t}+\frac{W_{\mathrm{s}}}{M_{\mathrm{FeO}}} \frac{d(\% \mathrm{FeO})}{d t} \\
& +\frac{W_{\mathrm{s}}}{M_{\mathrm{Fe}_{2} \mathrm{O}_{3}}} \frac{d\left(\% \mathrm{Fe}_{2} \mathrm{O}_{3}\right)}{d t}+\frac{W_{\mathrm{s}}}{M_{\mathrm{MnO}}} \frac{d(\% \mathrm{MnO})}{d t} .
\end{aligned}
$$

It is assumed that a part of top blown oxygen reacts with iron in the hot metal and $\mathrm{CO}$ being generated by decarburization, but not react with [C], [Si] nor [Mn] directly in the hot metal. The basis of this assumption is the behavior of [Si] and [Mn] shown in Figs. 3 to 6 in which decreasing rates of $[\mathrm{Si}]$ and $[\mathrm{Mn}]$ do not change by the termination of top blown oxygen. In addition, although $(\mathrm{FeO})$ and $\left(\mathrm{Fe}_{2} \mathrm{O}_{3}\right)$ contents in slag do not decrease during top oxygen blowing, 


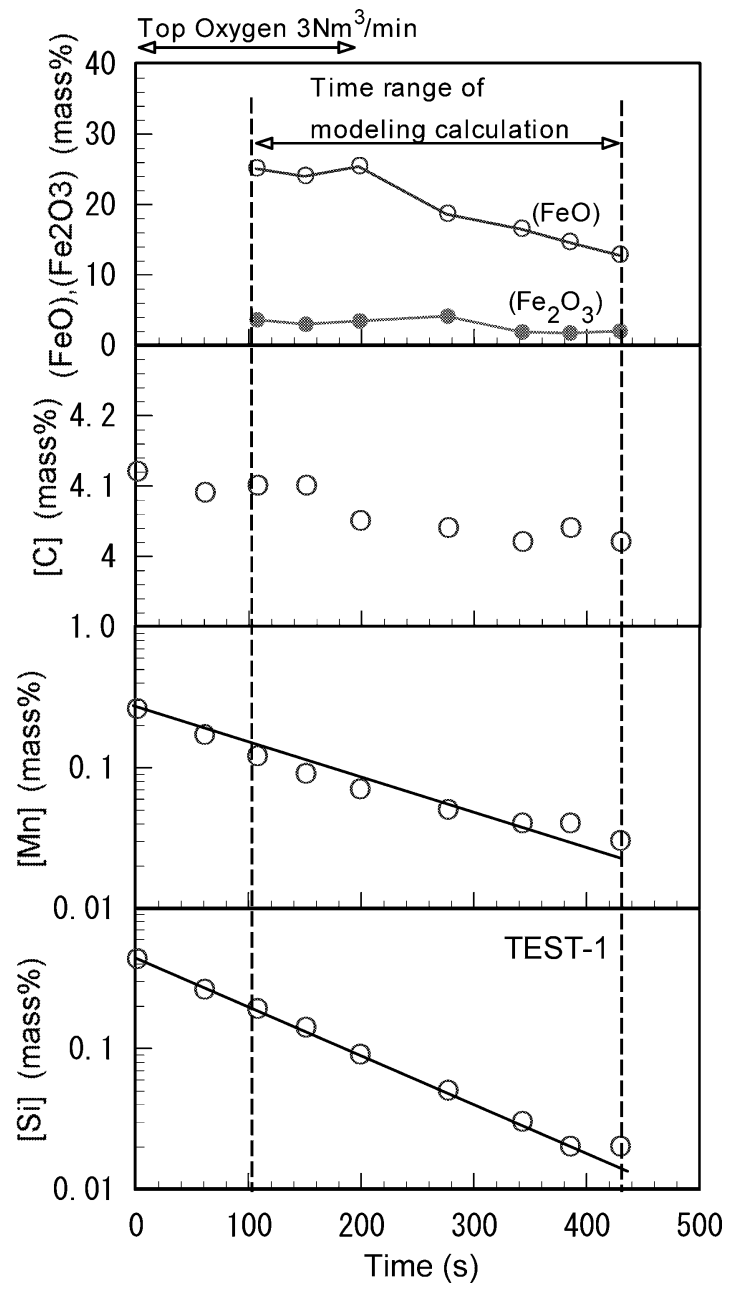

Fig. 3. Variations of $[\mathrm{Si}],[\mathrm{C}],(\mathrm{FeO})$ and $\left(\mathrm{Fe}_{2} \mathrm{O}_{3}\right)$ with time in TEST-1.

those decrease significantly by the termination of top blown oxygen as shown in Figs. 3 to 6 . From these facts, top blown oxygen is considered to react with slag to supply oxygen but not react with metal directly. It is also assumed that a ratio of $R_{\text {Top }}$ of top blown oxygen reacts with $\mathrm{FeO}$ in the slag to generate $\mathrm{Fe}_{2} \mathrm{O}_{3}$ and that the remained oxygen of $\left(1-R_{\mathrm{Top}}\right)$ reacts with $\mathrm{Fe}$ in the hot metal to generate $\mathrm{FeO}$.

From the oxygen balance calculation, it was clarified that oxygen which reacted with $\mathrm{CO}$ but not reacted with slag nor metal existed. By considering the oxygen which did not react with slag nor metal in the model, calculated behaviors of metal and slag elements coincided well with actual ones. Both actual top oxygen flow rates and modified top oxygen flow rates used in the model calculations considering the oxygen which did not reacted with metal nor slag are shown in Table 3.

Concentrations of elements in the slag and hot metal are calculated by considering oxygen balance at slag-metal interface and top blown oxygen as mentioned above.

$$
\begin{gathered}
{[\% \mathrm{X}]_{t+\Delta t}=[\% \mathrm{X}]_{t}+\frac{d[\% \mathrm{X}]}{d t} \Delta t} \\
(\% \mathrm{FeO})_{t+\Delta t}=(\% \mathrm{FeO})_{t} \\
+\left[\frac{d(\% \mathrm{FeO})}{d t}-\frac{2 \times 7 . . . . . .}{159.7} \cdot \frac{d\left(\% \mathrm{Fe}_{2} \mathrm{O}_{3}\right)}{d t}\right.
\end{gathered}
$$

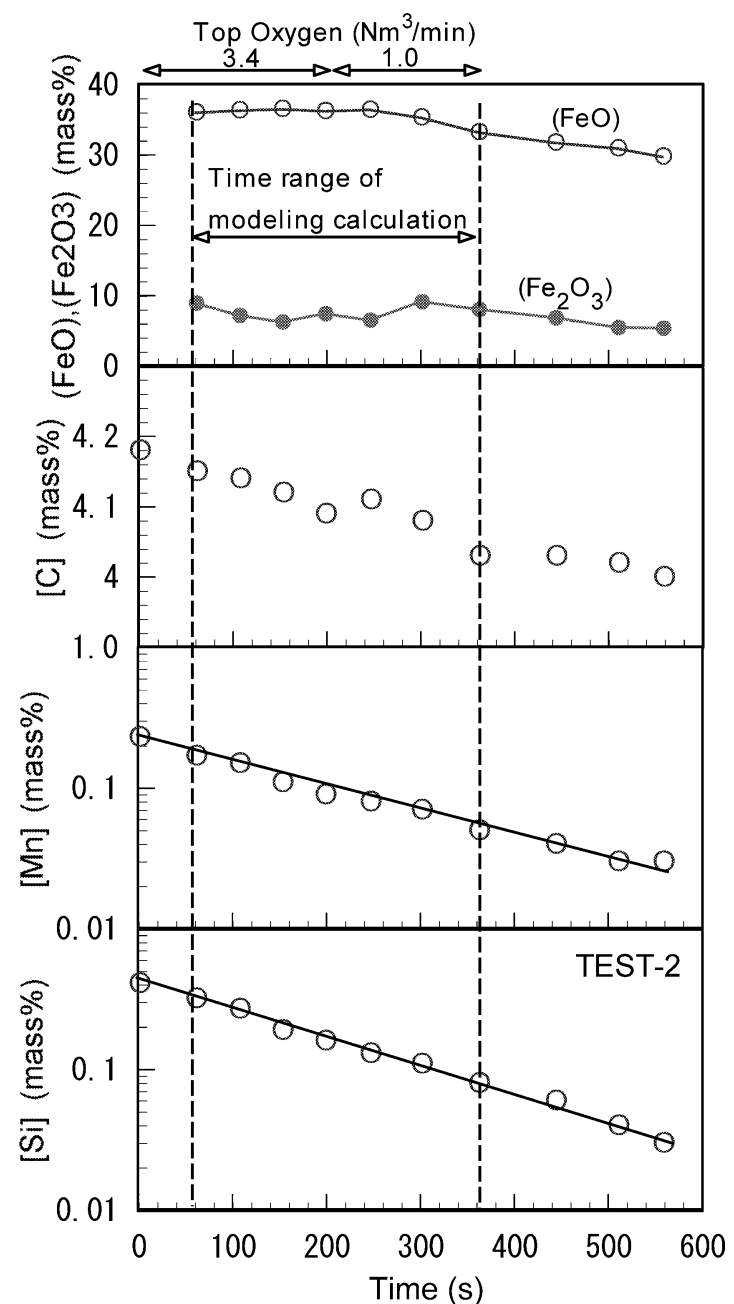

Fig. 4. Variations of $[\mathrm{Si}],[\mathrm{C}],(\mathrm{FeO})$ and $\left(\mathrm{Fe}_{2} \mathrm{O}_{3}\right)$ with time in TEST-2.

$$
\begin{gathered}
\left.+\frac{100 \times 71.85 \times Q_{\mathrm{O}_{2}}}{60 \times 11.2 \times W_{\mathrm{s}}} \cdot\left(1-3 \times R_{\mathrm{Top}}\right)\right] \Delta t \ldots \ldots \ldots \ldots . . . . . . . . \\
\left(\% \mathrm{Fe}_{2} \mathrm{O}_{3}\right)_{t+\Delta t}=\left(\% \mathrm{Fe}_{2} \mathrm{O}_{3}\right)_{t} \\
+\left[\frac{d\left(\% \mathrm{Fe}_{2} \mathrm{O}_{3}\right)}{d t}+\frac{100 \times 159.7 \times Q_{\mathrm{O}_{2}}}{60 \times 11.2 \times W_{\mathrm{s}}} \cdot R_{\mathrm{Top}}\right] \Delta t
\end{gathered}
$$

where,

$\mathrm{X}: \quad \mathrm{C}, \mathrm{Si}, \mathrm{Mn}, \mathrm{P}, \mathrm{O}$

$Q_{\mathrm{O}_{\mathrm{O}}}$ : oxygen amount react with $\mathrm{Fe}$ and $\mathrm{FeO}\left(\mathrm{Nm}^{3} / \mathrm{min}\right)$

$\Delta t$ : time interval in model calclation ( $1 \mathrm{~s})$

\section{Experimental Results}

Figure 3 to 6 show the variation of concentrations of [Si], [Mn], [C] in hot metal and $(\mathrm{FeO}),\left(\mathrm{Fe}_{2} \mathrm{O}_{3}\right)$ in slag in four experiments. In each experiment, the logarithm of [Si] and [Mn] decrease linearly with time at same inclination both with and without top oxygen blowing. From this result, top blown oxygen did not react either with [Si] or [Mn] in hot metal under the condition of these experiments. In the TEST-1 with a strong bottom blowing, the decreasing rates of [Si] and $\mathrm{FeO}$ in slag after the termination of top oxygen blowing were larger than those in other experiments al- 


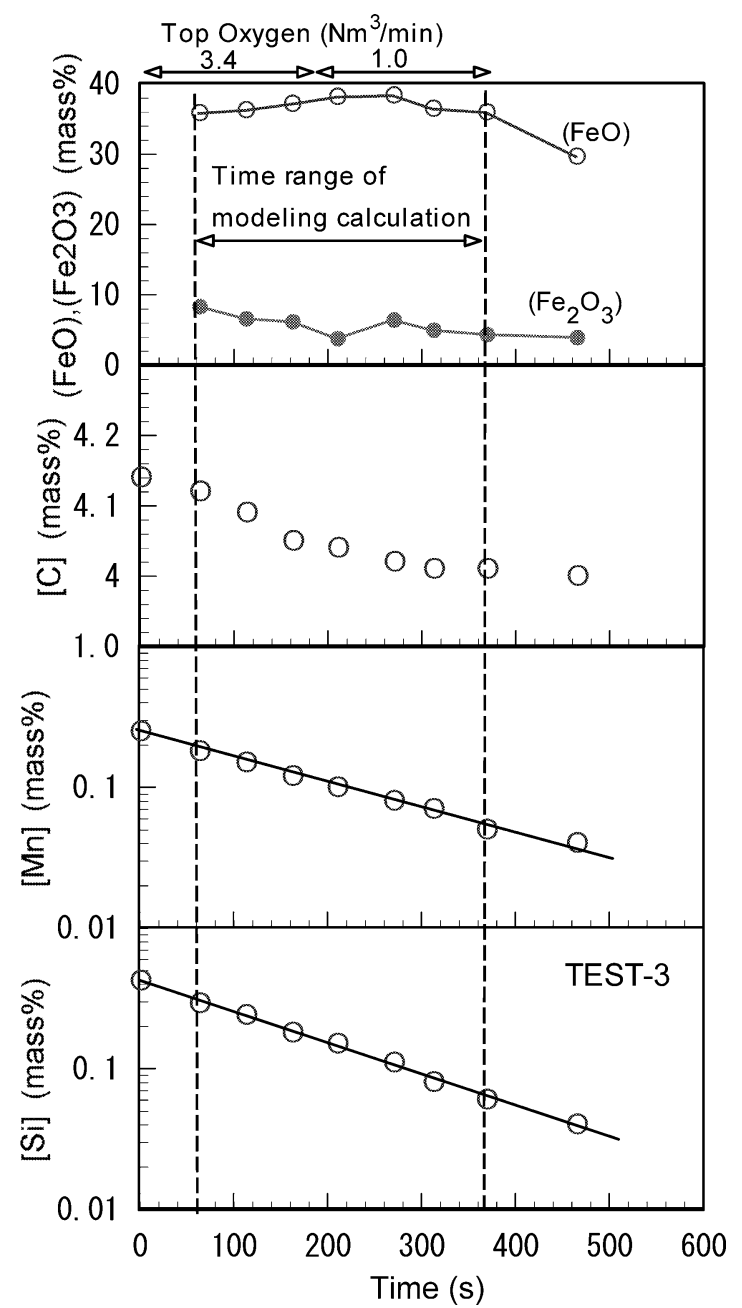

Fig. 5. Variations of $[\mathrm{Si}],[\mathrm{C}],(\mathrm{FeO})$ and $\left(\mathrm{Fe}_{2} \mathrm{O}_{3}\right)$ with time in TEST-3.

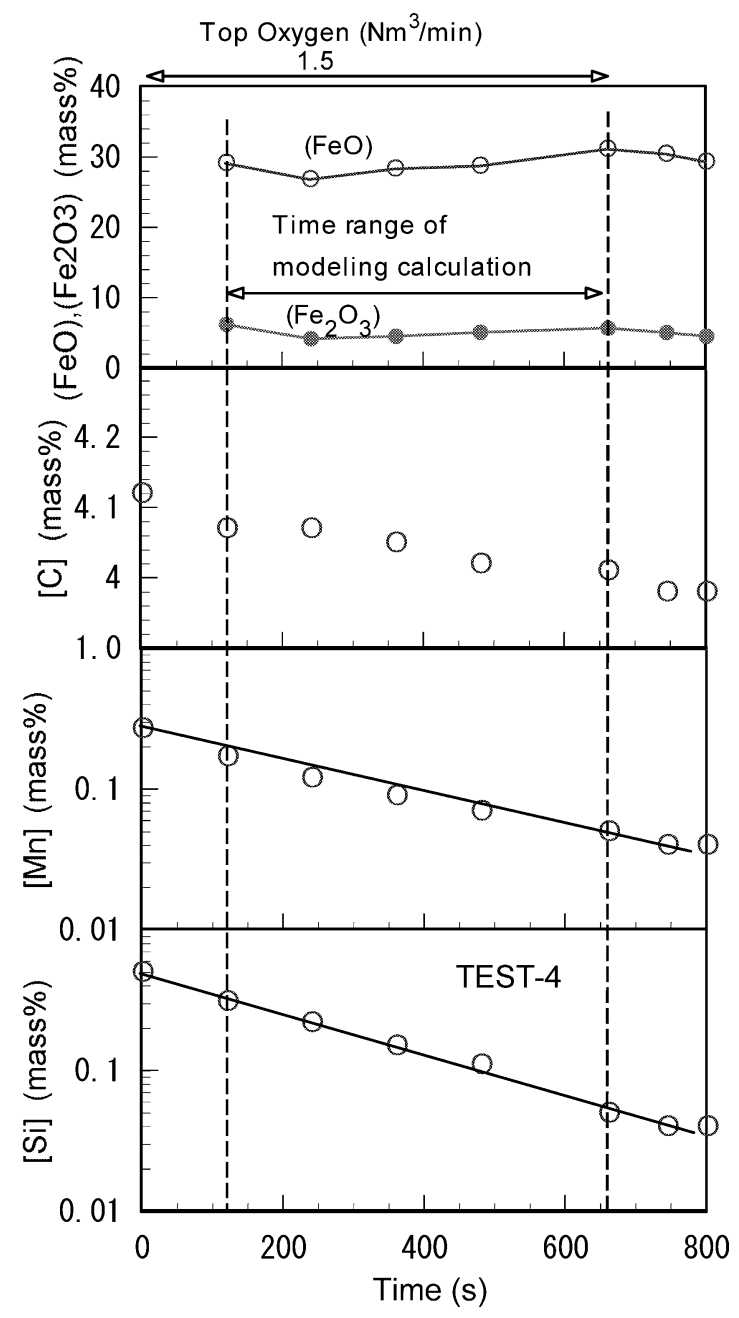

Fig. 6. Variations of $[\mathrm{Si}],[\mathrm{C}],(\mathrm{FeO})$ and $\left(\mathrm{Fe}_{2} \mathrm{O}_{3}\right)$ with time in TEST-4.

Table 3. Parameters determined by modeling calculations.

\begin{tabular}{|c|c|c|c|c|c|c|c|c|c|c|c|c|}
\hline \multicolumn{2}{|c|}{ TEST No. } & \multirow{2}{*}{$\begin{array}{l}\text { Time } \\
\begin{array}{l}91.2 \\
\mathrm{~s}\end{array} \\
\end{array}$} & \multicolumn{2}{|c|}{ Top $\mathrm{O}_{2} \mathrm{Nm}^{3} / \mathrm{min}$} & \multirow{3}{*}{\begin{tabular}{|l}
$\mathrm{km} \rho \mathrm{m}$ \\
$\begin{array}{l}27 \\
\mathrm{~kg} / \mathrm{m}^{2} \mathrm{~s}\end{array}$
\end{tabular}} & \multirow{2}{*}{$\begin{array}{l}\mathrm{ks} \rho \mathrm{s} \\
0.7 \\
\mathrm{~kg} / \mathrm{m}^{2} \mathrm{~s}\end{array}$} & \multirow{3}{*}{\begin{tabular}{|l|}
\multicolumn{1}{|c|}{$\mathrm{kc}$} \\
1 \\
$\mathrm{~kg} / \mathrm{m}^{2} \mathrm{~s}$
\end{tabular}} & \multirow{3}{*}{\begin{tabular}{|l|} 
Lo $^{*}$ \\
1300 \\
\end{tabular}} & \multirow{3}{*}{\begin{tabular}{|l|}
$\left(\mathrm{Lo}^{*}\right)_{2}$ \\
500
\end{tabular}} & \multirow{2}{*}{$\begin{array}{l}\text { BMn } \\
9.0 \\
\times 10^{4}\end{array}$} & \multirow{2}{*}{\begin{tabular}{|l|}
\multicolumn{1}{|c}{$\mathrm{BP}$} \\
$\begin{array}{l}2.0 \\
\times 10^{7}\end{array}$ \\
\end{tabular}} & \multirow{2}{*}{\begin{tabular}{|l} 
RTop \\
0.055 \\
\end{tabular}} \\
\hline \multirow[t]{2}{*}{1} & $\begin{array}{l}\text { First } \\
\text { period }\end{array}$ & & 3.0 & 1.56 & & & & & & & & \\
\hline & $\begin{array}{l}\text { Second } \\
\text { period }\end{array}$ & \begin{tabular}{|l}
231 \\
$\mathrm{~S}$
\end{tabular} & 0 & 0 & & $\begin{array}{l}0.3 \\
\mathrm{~kg} / \mathrm{m}^{2} \mathrm{~s}\end{array}$ & & & & $\begin{array}{l}2.0 \\
\times 10^{5} \\
\end{array}$ & $\begin{array}{l}2.0 \\
\times 10^{6} \\
\end{array}$ & - \\
\hline \multirow[t]{2}{*}{2} & $\begin{array}{l}\text { First } \\
\text { period }\end{array}$ & $\begin{array}{l}137.4 \\
\mathrm{~S}\end{array}$ & 3.4 & 1.598 & \multirow[t]{2}{*}{$\begin{array}{l}13 \\
\mathrm{~kg} / \mathrm{m}^{2} \mathrm{~s}\end{array}$} & $\begin{array}{l}0.7 \\
\mathrm{~kg} / \mathrm{m}^{2} \mathrm{~s}\end{array}$ & \multirow[t]{2}{*}{0.55} & \multirow[t]{2}{*}{1300} & \multirow[t]{2}{*}{500} & $\begin{array}{l}1.4 \\
\times 10^{4} \\
\end{array}$ & $\begin{array}{l}1.6 \\
\times 10^{7}\end{array}$ & 0.07 \\
\hline & $\begin{array}{l}\text { Second } \\
\text { period }\end{array}$ & $\begin{array}{l}163.8 \\
\mathrm{~s} \\
\end{array}$ & 1.0 & 0.78 & & $\begin{array}{l}0.4 \\
\mathrm{~kg} / \mathrm{m}^{2} \mathrm{~s}\end{array}$ & & & & $\begin{array}{l}2.7 \\
\times 10^{4}\end{array}$ & $\begin{array}{l}8.0 \\
\times 10^{6} \\
\end{array}$ & 0.08 \\
\hline \multirow[t]{2}{*}{3} & $\begin{array}{l}\text { First } \\
\text { period }\end{array}$ & $\begin{array}{l}147 \\
\mathrm{~s}\end{array}$ & 3.4 & 1.666 & \multirow[t]{2}{*}{$\begin{array}{l}13 \\
\mathrm{~kg} / \mathrm{m}^{2} \mathrm{~s}\end{array}$} & $\begin{array}{l}0.65 \\
\mathrm{~g} / \mathrm{cm}^{2} \mathrm{~s}\end{array}$ & \multirow[t]{2}{*}{0.55} & \multirow[t]{2}{*}{1300} & \multirow[t]{2}{*}{500} & $\begin{array}{l}1.0 \\
\times 10^{4}\end{array}$ & $\begin{array}{l}8.0 \\
\times 10^{6}\end{array}$ & 0 \\
\hline & $\begin{array}{l}\text { Second } \\
\text { period }\end{array}$ & \begin{tabular}{|l}
159 \\
$\mathrm{~s}$
\end{tabular} & 1.0 & 0.70 & & $\begin{array}{l}0.4 \\
\mathrm{~kg} / \mathrm{m}^{2} \mathrm{~s}\end{array}$ & & & & $\begin{array}{l}2.5 \\
\times 10^{4}\end{array}$ & $\begin{array}{l}6.0 \\
\times 10^{6} \\
\end{array}$ & 0 \\
\hline \multirow[t]{2}{*}{4} & $\begin{array}{l}\text { First } \\
\text { period }\end{array}$ & $\begin{array}{l}240 \\
\mathrm{~s} \\
\end{array}$ & 1.5 & 0.705 & \multirow[t]{2}{*}{$\begin{array}{l}10 \\
\mathrm{~kg} / \mathrm{m}^{2} \mathrm{~S}\end{array}$} & $\begin{array}{l}0.32 \\
\mathrm{~kg} / \mathrm{m}^{2} \mathrm{~s}\end{array}$ & \multirow[t]{2}{*}{0.55} & \multirow[t]{2}{*}{1300} & \multirow[t]{2}{*}{500} & $\begin{array}{l}1.4 \\
\times 10^{5} \\
\end{array}$ & $\begin{array}{l}1.6 \\
\times 10^{9} \\
\end{array}$ & 0.08 \\
\hline & $\begin{array}{l}\text { Second } \\
\text { period }\end{array}$ & $\begin{array}{l}300.6 \\
\mathrm{~s}\end{array}$ & 1.5 & 0.705 & & $\begin{array}{l}0.29 \\
\mathrm{~kg} / \mathrm{m}^{2} \mathrm{~s}\end{array}$ & & & & $\begin{array}{l}3.4 \\
\times 10^{4}\end{array}$ & $\begin{array}{l}1.5 \\
\times 10^{7}\end{array}$ & 0.08 \\
\hline
\end{tabular}

though the amount of added oxygen in sinter ore and top blown oxygen was smaller. In the TEST-4 with a small top oxygen blowing, $\mathrm{FeO}$ content in slag and [Si] decreasing rate were lower than those in TEST-2 and TEST-3 with larger top oxygen blowing although the amount of added sinter ore and bottom blowing flow rate were the same.

\section{Result of Analysis by the Coupled Reaction Model}

Reaction behaviors in four heats were analyzed by the coupled reaction model, and reaction mechanism was investigated. As the oxygen flow rate and iron oxide content in slag were changed in the first and second half of each 


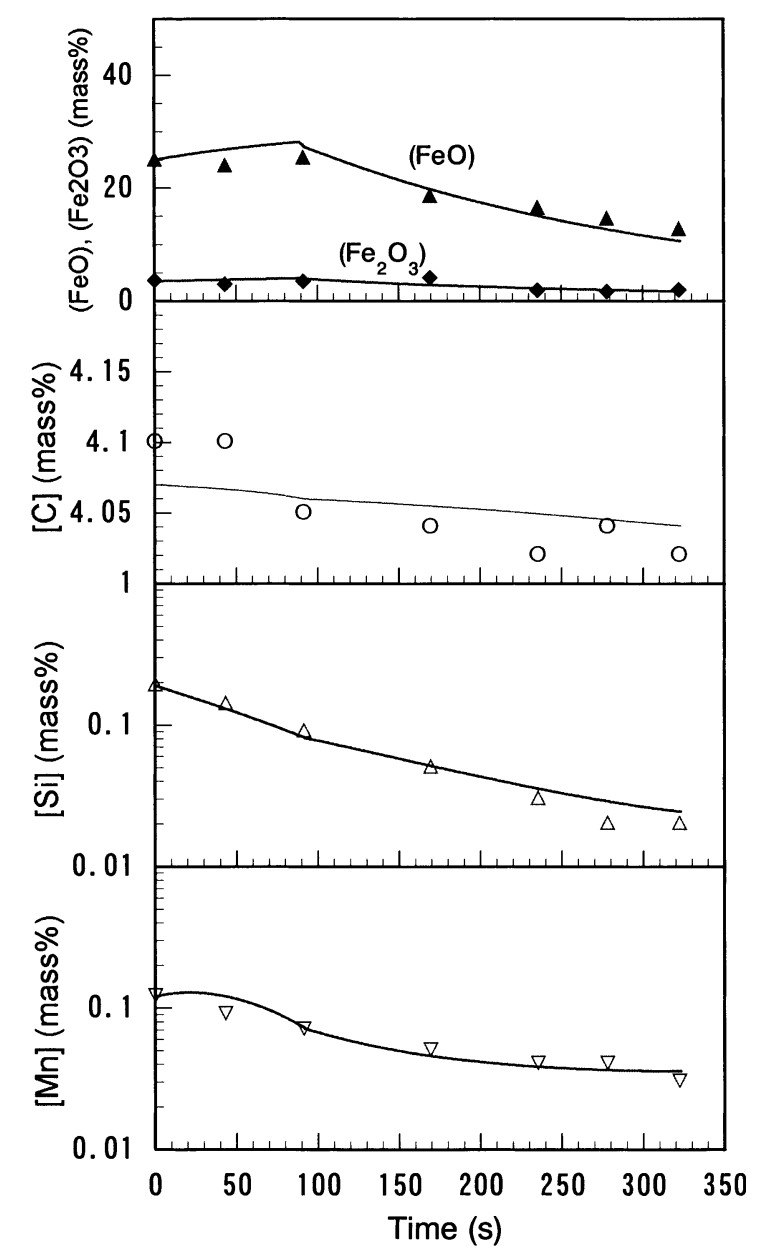

Fig. 7. Comparison of actual and calculated values of each element in TEST-1.

heat, they were analyzed independently using the coupled reaction model. Parameters obtained in the coupled reaction model analysis are shown in Table 3. By using these parameters, estimated behaviors of slag and metal components by the coupled reaction model analysis coincided well with the actual ones as shown in Figs. 7 to $\mathbf{1 0 .}$

\section{Discussion}

\subsection{Mass Transfer Coefficient in Metal}

As shown in Table 3, the product of mass transfer coefficient in metal and the density of metal did not change in the first and second half of each heat. The mass transfer coefficient in metal was proportional to 0.73 power of agitation energy of hot metal as shown in Fig. 11. The reason of this is that the mass transfers of silicon and manganese were enhanced and the interfacial area was increased by the agitation.

In order to compare the results in this work with other works, the relationship of mass transfer coefficient in metal and $\varepsilon / d_{\mathrm{c}}^{2}$ was investigated, where $\varepsilon$ is the agitation energy calculated by Eq. (30) in Appendix and $d_{\mathrm{c}}$ is the diameter of vessel. The result is shown in Fig. 12. Mukawa et al. ${ }^{6)}$ reported that the mass transfer coefficient in metal was proportional to 0.7 power of $\varepsilon / d_{\mathrm{c}}^{2}$ in the measurement of desiliconization rate. This dependency of the mass transfer coefficient in metal on $\varepsilon / d_{\mathrm{c}}^{2}$ is almost the same as this work. On

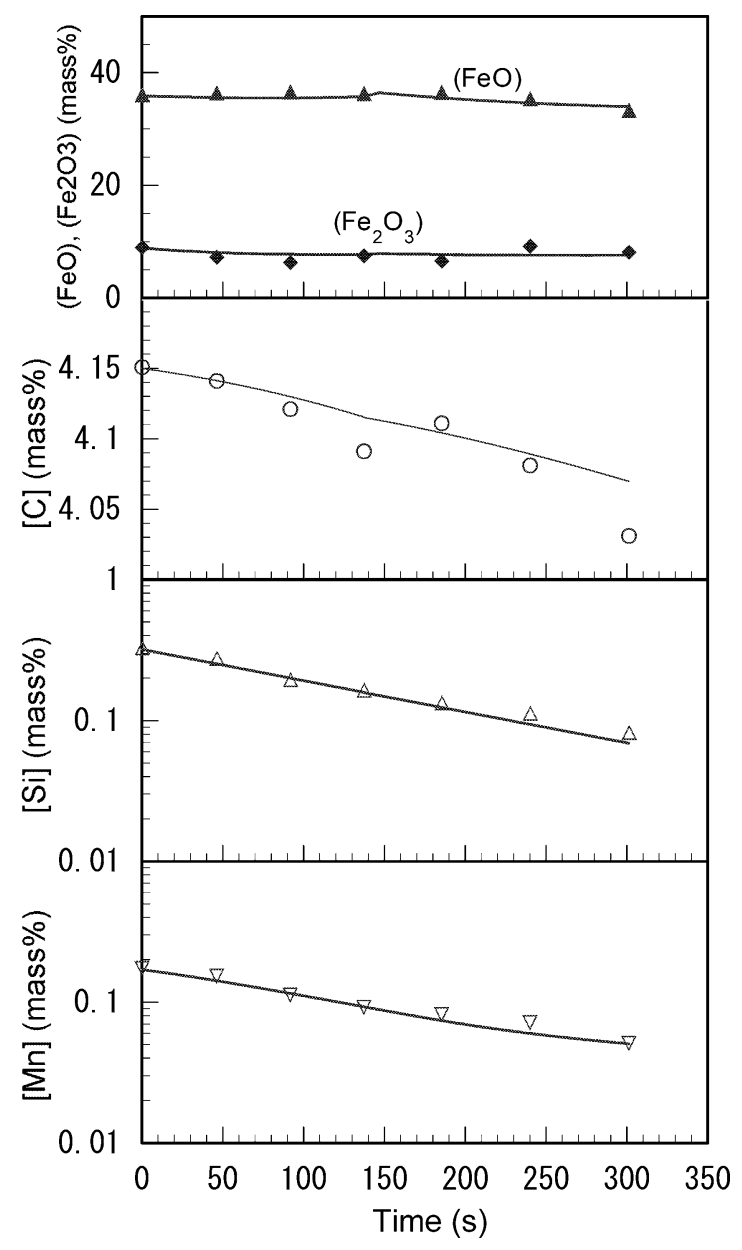

Fig. 8. Comparison of actual and calculated values of each element in TEST-2.

the other hand, Kitamura et $a .^{7)}$ reported that the mass transfer coefficient in metal was proportional to 0.5 power of $\varepsilon / d_{\mathrm{c}}^{2}$. Higuchi et al. ${ }^{8)}$ also reported that the mass transfer coefficient in metal was proportional to 0.5 power of $\varepsilon / d_{\mathrm{c}}^{2}$ in the measurement of oxidation of aluminum in molten steel. In these previous works, dependency of the mass transfer coefficient in metal on $\varepsilon / d_{\mathrm{c}}^{2}$ is smaller than that obtained in this work. The reason of the smaller dependency of the mass transfer coefficient in metal on $\varepsilon / d_{\mathrm{c}}^{2}$ in these works is considered that smaller interfacial area caused by weak agitation makes the mass transfer coefficient in metal smaller apparently.

\subsection{Mass Transfer Coefficient in Slag}

As shown in Fig. 13, the product of mass transfer coefficient in slag and the density of slag $k_{\mathrm{s}} \rho_{\mathrm{s}}$ increased with increasing average $\mathrm{FeO}$ content in slag during the experimental periods. The reason of this result seems that slag viscosity and melting temperature were decreased with increasing $\mathrm{FeO}$ content in slag ${ }^{9,10)}$ and mass transfer in slag was enhanced with the decreased slag viscosity and melting temperature. Also, under the same FeO content, $k_{\mathrm{s}} \rho_{\mathrm{s}}$ increased with agitation energy of metal. This is seemed to be caused by the stronger agitation energy of slag and larger slagmetal interfacial area under the stronger metal agitation as will be mentioned later.

As shown in Table $3, k_{\mathrm{s}} \rho_{\mathrm{s}}$ in TEST-1 was almost the same as TEST-2 and TEST-3 although the agitation energy 


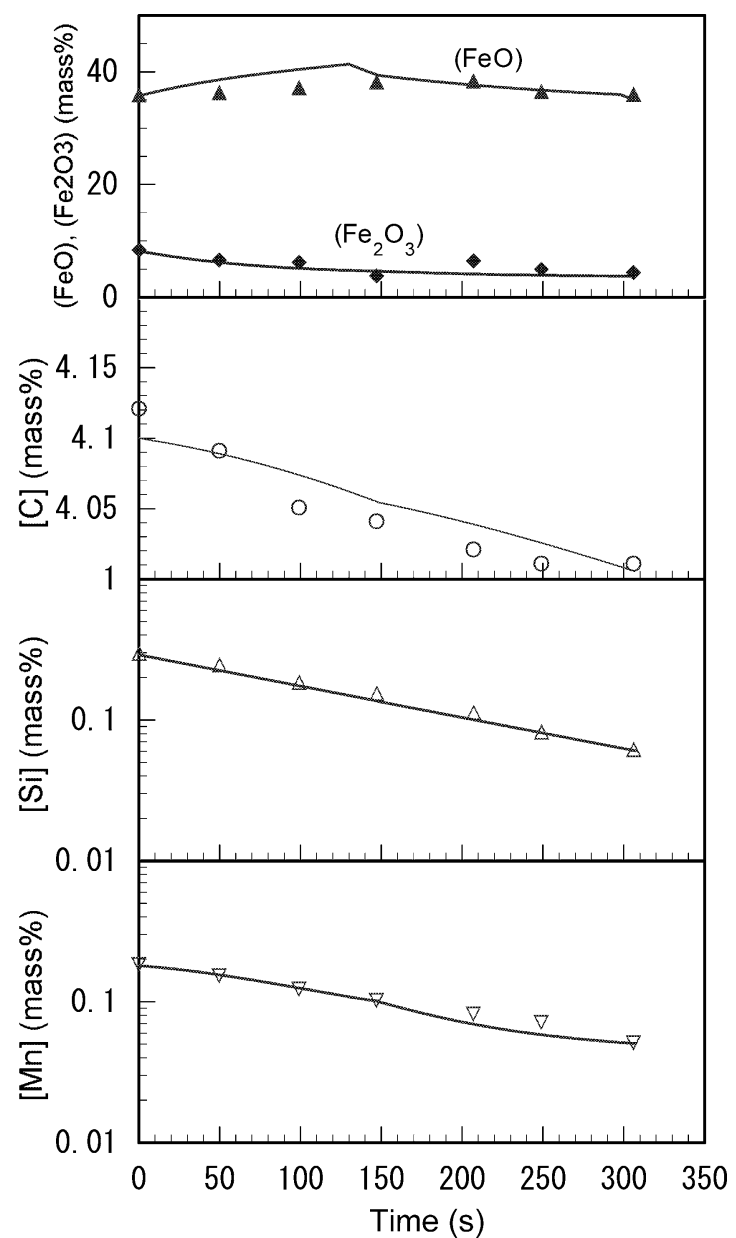

Fig. 9. Comparison of actual and calculated values of each element in TEST-3.

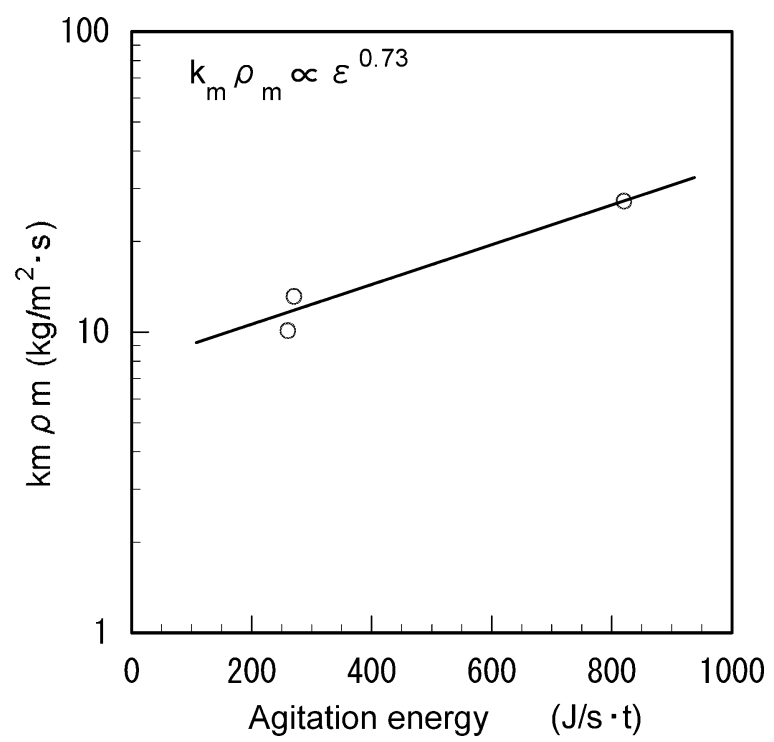

Fig. 11. Relationship between agitation energy and $k_{\mathrm{m}} \rho_{\mathrm{m}}$.

in TEST-1 was higher than that in TEST-2 and TEST-3. In TEST-1, FeO content in slag was lower than in TEST-2 and TEST-3 because of stronger agitation. Therfore FeO mass transfer in slag was suppressed by the decrease of slag viscosity. But the stronger agitation in TEST-1 enhanced FeO mass transfer in slag. Consequently, it seems that the decrease of slag viscosity canseled stronger agitation, result-

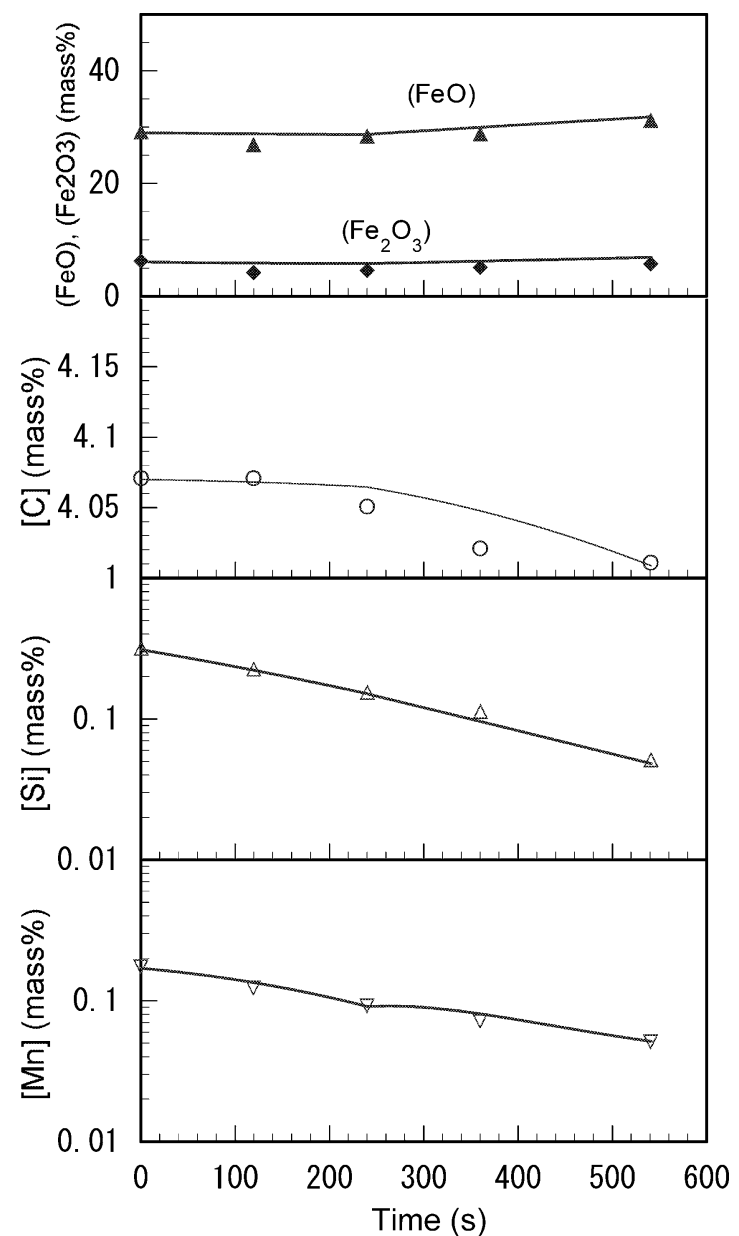

Fig. 10. Comparison of actual and calculated values of each element in TEST-4.

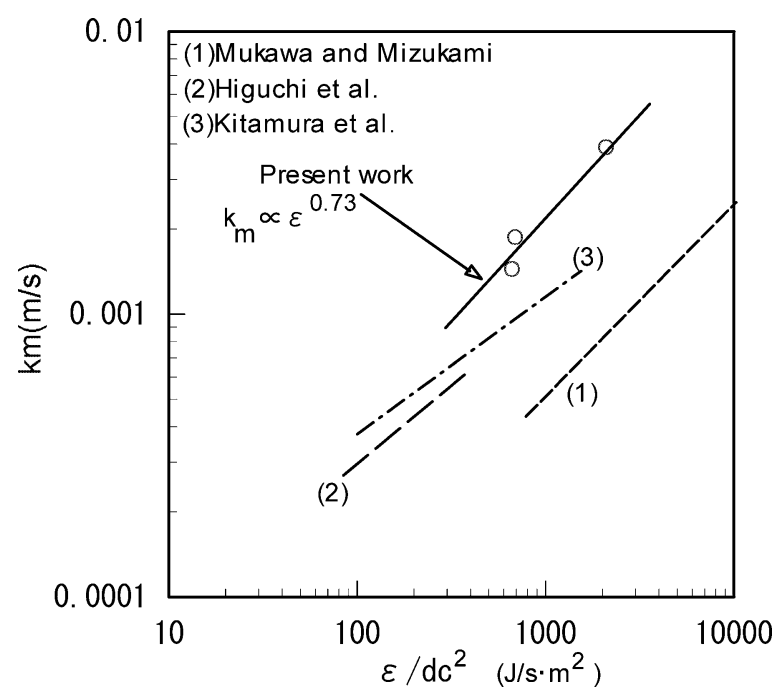

Fig. 12. Relationship between $\varepsilon / d_{\mathrm{c}}^{2}$ and $k_{\mathrm{m}}$.

ing in almost the same $k_{\mathrm{s}} \rho_{\mathrm{s}}$ as TEST-2 and TEST-3 in TEST-1. However, in the region of $\mathrm{FeO}$ content larger than $35 \%$, the change of $k_{\mathrm{s}} \rho_{\mathrm{s}}$ has almost no effect on the desiliconization rate because transfer resistance of slag is negligible to that of metal. 


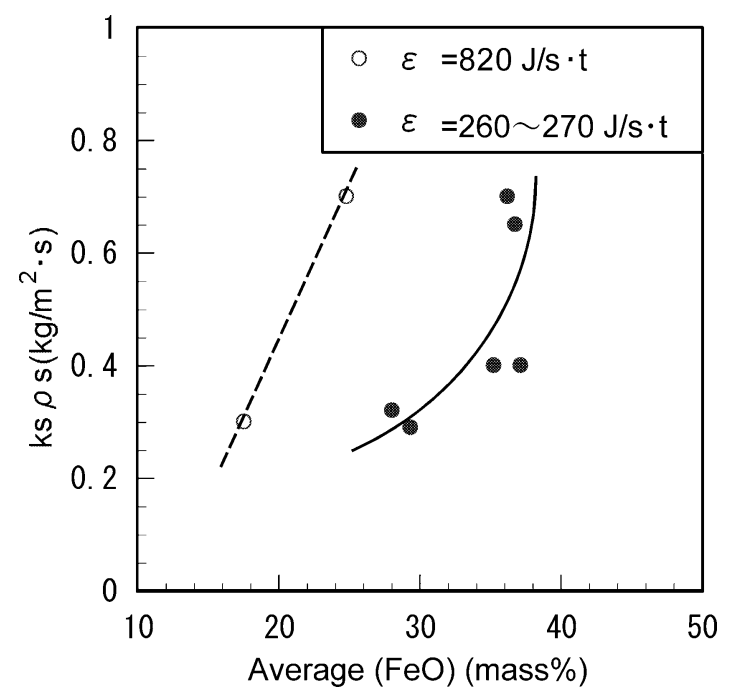

Fig. 13. Relationship between measured $(\mathrm{FeO})$ and $k_{\mathrm{s}} \rho_{\mathrm{s}}$.

\subsection{Reaction Rate Constant of Decarburization}

Reaction rate constant of decarburization was larger in TEST-1 in which agitation energy of metal was larger than that in TEST-2 and TEST-3. Decarburization rate is not affected essentially by agitation energy because it is controlled by chemical reaction but is not controlled by mass transfer in metal or slag. It seems that the disturbance of slag-metal interface increased with agitation energy, and then the interfacial area increased, ${ }^{11,12)}$ thus apparent rate of decarburization increased.

Consequently, it seems that apparent mass transfer coefficients in metal and slag increased with agitation energy both by the enhanced mass transfer and the increased interfacial area in the case of strong agitation.

\subsection{Comparison of Transport Resistance in Metal and That in Slag}

Shibata et al. defined ratio of transport resistance in metal and that in slag to overall resistance, $X_{\mathrm{m}}$ and $X_{\mathrm{s}}$ respectively, to compare the contribution of metal and slag resistance in transport of silicon and manganese etc. ${ }^{3)}$ These ratios of transport resistance were applied to reaction behaviors in this work. After Shibata et al., the ratio of transport resistance in slag to overall resistance, $X_{\mathrm{s}}^{\mathrm{Si}}$, is given by Eq. (26):

$$
X_{\mathrm{s}}^{\mathrm{Si}}=\frac{1}{k_{\mathrm{s}} \rho_{\mathrm{s}} R_{\mathrm{Si}}}
$$

where $R_{\mathrm{Si}}$ is overall resistance to silicon transport in metal and slag which is given by Eq. (27).

$$
R_{\mathrm{Si}}=\frac{L_{\mathrm{Si}}^{*}}{k_{\mathrm{m}} \rho_{\mathrm{m}}}+\frac{1}{k_{\mathrm{s}} \rho_{\mathrm{s}}}
$$

The ratio of transport resistance in slag to overall resistance, $X_{\mathrm{s}}^{\mathrm{Si}}$, was calculated in time intervals mentioned above, and was plotted against average analyzed $\mathrm{FeO}$ concentration during the time intervals. As shown in Fig. 14, $X_{\mathrm{s}}^{\mathrm{Si}}$ was affected both by $\mathrm{FeO}$ in slag and [Si] in metal. $X_{\mathrm{s}}^{\mathrm{S}}$ increased by the decrease of $(\mathrm{FeO})$ in slag and the increase of [Si] in metal. In the condition of this work, $X_{\mathrm{s}}^{\mathrm{Si}}$ decreased

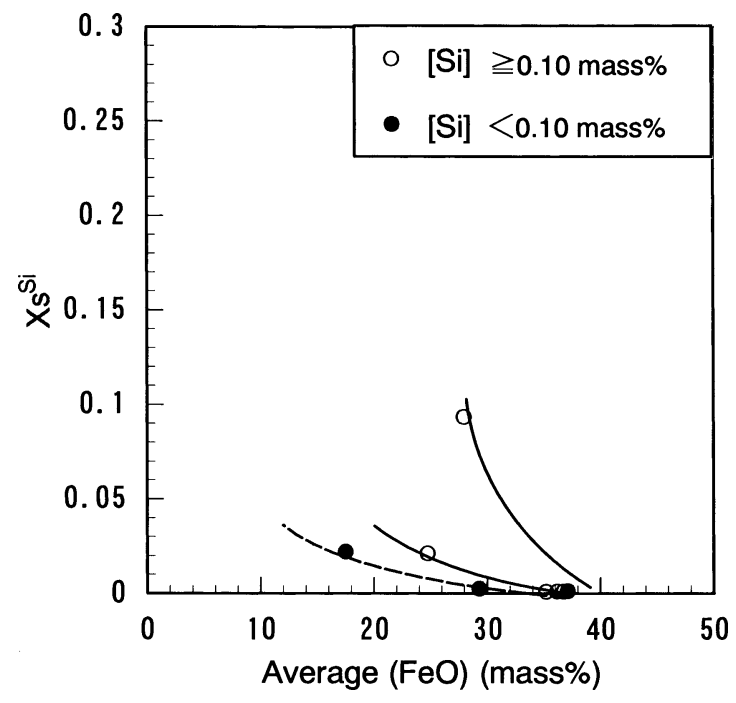

Fig. 14. Relationship between measured $(\mathrm{FeO})$ and $X_{\mathrm{s}}^{\mathrm{Si}}$.

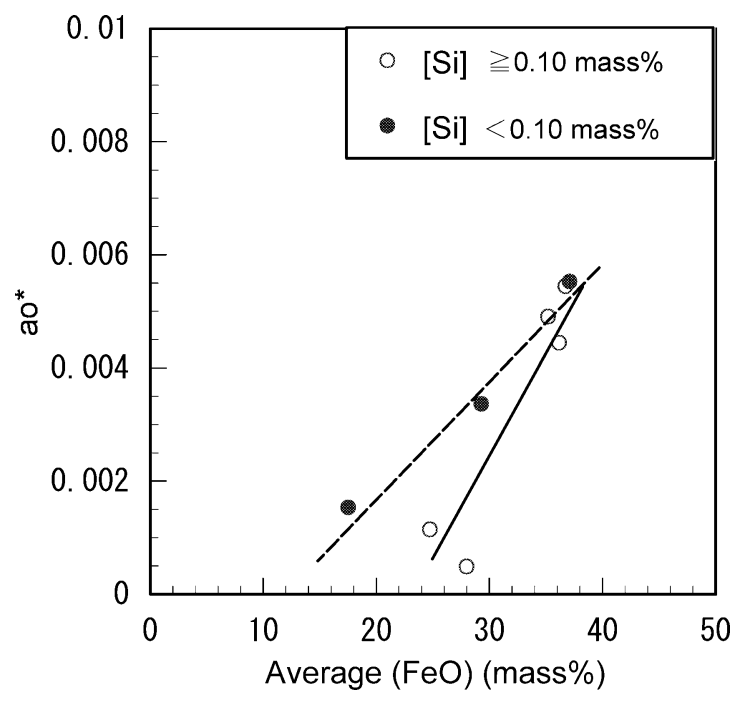

Fig. 15. Relationship between measured $(\mathrm{FeO})$ and $a_{0}^{*}$.

to almost zero when (FeO) in slag was larger than 35 mass \%. In this case, desiliconization reaction seems to be controlled by the mass transfer in the metal as pointed out by Narita et al. ${ }^{1)}$

Although $X_{\mathrm{s}}^{\mathrm{Si}}$ increased to larger than 0.8 in the final stage of reaction in the crucible experiments done by Shibata et al., ${ }^{3)} X_{\mathrm{s}}^{\mathrm{Si}}$ was smaller than 0.1 when [Si] in metal decreased to lower level in the final stage of reaction in experiments of this work. This seems to be caused by higher (FeO) content in slag than in the crucible experiments done by Shibata et al.

\subsection{Effects of (FeO) in Slag on Oxygen Activity $a_{0}^{*}$ at the Slag-Metal Interface}

Relationship between average $(\mathrm{FeO})$ in slag and interfacial oxygen activity $a_{0}^{*}$ is shown in Fig. 15. Interfacial oxygen activity increased with increasing $(\mathrm{FeO})$ in slag. Also it increased by the decrease of [Si] content in metal because desiliconization reaction rate decreased and supply of oxygen to the slag/metal interface was excessive in this case. Those seem to be corresponding that higher $(\mathrm{FeO})$ and lower [Si] result in lower $X_{\mathrm{s}}^{\mathrm{Si}}$ as already mentioned. 


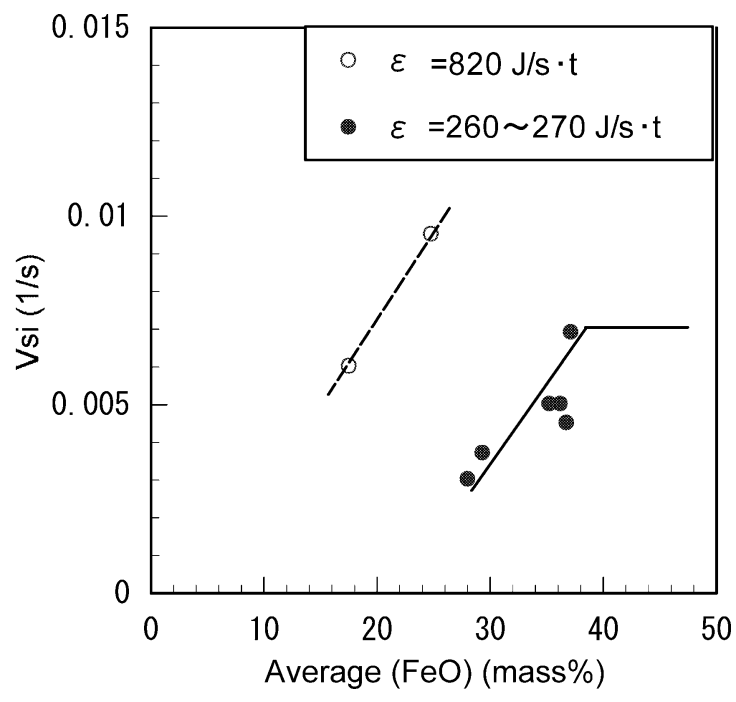

Fig. 16. Relationship between measured $(\mathrm{FeO})$ and $V_{\mathrm{Si}}$.

Shibata et $\mathrm{al}^{3}{ }^{3)}$ reported that interfacial oxygen activity was around $10^{-4}$ to $10^{-2}$ in the crucible experiments. Interfacial oxygen activity obtained in this work was almost the same as Shibata's result as shown in Fig. 15.

\subsection{Effect of ( $\mathrm{FeO})$ in Slag and Agitation Energy on Apparent Volumetric Rate Constant}

Figure 16 shows the relationship between $(\mathrm{FeO})$ in slag and apparent volumetric rate constant $V_{\mathrm{S}}$, defined by Eq. (28). Higher $(\mathrm{FeO})$ and agitation energy resulted in larger $V_{\mathrm{Si}}$. This seems to be a result of enhanced mass transfer in metal and slag caused by stronger agitation, enhanced mass transfer in slag caused by higher $(\mathrm{FeO})$ content in slag and larger driving force caused by higher oxygen activity at the slag-metal interface.

$$
V_{\mathrm{Si}}=\frac{1}{t} \ln \frac{[\% \mathrm{Si}]_{\mathrm{i}}}{[\% \mathrm{Si}]_{\mathrm{f}}}
$$

where,

$$
\begin{aligned}
{[\% \mathrm{Si}]_{\mathrm{i}},[\% \mathrm{Si}]_{\mathrm{f}}: } & \begin{array}{l}
\text { silicon content in metal before and after } \\
\text { the experiment }
\end{array} \\
t: & \text { reaction time }(\mathrm{s})
\end{aligned}
$$

It is not clarified in this work whether $V_{\mathrm{Si}}$ is increased with $(\mathrm{FeO})$ or not in the region where $(\mathrm{FeO})$ is larger than 35 mass\%. However, $X_{\mathrm{s}}^{\mathrm{Si}}$ approaches to almost zero as already mentioned, and mass transfer in slag seems to have no effect in desiliconization rate in this region. Thus, $V_{\mathrm{Si}}$ is thought to be almost constant independently of $(\mathrm{FeO})$ content in slag.

\subsection{Condition for Preferable Desiliconization Reac- tion}

Desiliconization rate is large in strong agitation even though $(\mathrm{FeO})$ content in slag is low. This is caused both by larger interfacial area and enhanced mass transfer in metal and slag. Decarburization reaction rate is also large in strong agitation, but this caused only by larger interfacial area. Consequently, dependency of reaction rate to agitation power is larger in desiliconization reaction than that in decarburization reaction.
From the results mentioned above, strong agitation and low $(\mathrm{FeO})$ content in slag are effective for preferable desiliconization reaction with suppressing the decarburization reaction.

\section{Conclusions}

Desiliconization behavior was analyzed using the coupled reaction model. Results obtained by the analysis are summarized as follows.

(1) The product of mass transfer coefficient in hot metal and density of hot metal is proportional to 0.73 power of agitation energy. This dependency includes the effect of change in the interfacial area and the result coincides with that of Mukawa et al. ${ }^{6}$

(2) The product of mass transfer coefficient in slag and density of slag is affected both by $(\mathrm{FeO})$ content in slag and agitation energy.

(3) The ratio of transport resistance in slag to overall resistance, $X_{\mathrm{s}}^{\mathrm{Si}}$, is affected both by $\mathrm{FeO}$ in slag and [Si] in metal. $X_{\mathrm{s}}^{\mathrm{Si}}$ increases by the decrease of $(\mathrm{FeO})$ in slag and the increase of [Si] in metal. In the condition of this work, $X_{\mathrm{s}}^{\mathrm{Si}}$ decreases to almost zero when $(\mathrm{FeO})$ in slag is larger than 35 mass\%. In this case, desiliconization reaction seems to be controlled by the mass transfer in the metal as pointed out by Narita et al. ${ }^{1)}$

(4) Higher $(\mathrm{FeO})$ and agitation energy causes larger $V_{\mathrm{Si}}$. This seems to be a result of enhanced mass transfer in metal and slag caused by stronger agitation, enhanced mass transfer in slag caused by higher $(\mathrm{FeO})$ content in slag and larger driving force caused by higher oxygen activity at the slag/metal interface.

(5) Strong agitation and low $(\mathrm{FeO})$ content in slag are effective for preferable desiliconization reaction with suppressing the decarburization reaction.

\section{Acknowledgments}

This work was done as a part of the research group activity in Iron and Steel Institute of Japan for slag minimization in steelmaking process. The author wishes to thank members of the research group for their effective discussions and suggestions in completing this study.

\section{REFERENCES}

1) K. Narita, T. Makino, H. Matsumoto, A. Hikosaka and J. Katsuta: Tetsu-to-Hagané, 69 (1983), 1722.

2) I. Han, M. Sano, M. Hirasawa and K. Mori: Tetsu-to-Hagané, 74 (1988), 61

3) E. Shibata, H. Sato and K. Mori: Tetsu-to-Hagané, 85 (1999), 639.

4) Y. Morita, Y. Nakai, H. Matsuno and Y. Kikuchi: CAMP-ISIJ, 14 (2001), 95.

5) S. Ohguchi, D. G. C. Robertson, B. Deo, P. Grieveson and J. E. Jeffes: Ironmaking Steelmaking, 1 (1984), 202.

6) S. Mukawa and Y. Mizukami: Tetsu-to-Hagané, 80 (1994), 207.

7) S. Kitamura, T. Kitamura, K. Shibata, Y. Mizukami, S. Mukawa and J. Nakagawa: ISIJ Int., 31 (1991), 1322.

8) Y. Higuchi, Y. Tago, K. Takatani and S. Fukagawa: Tetsu-to-Hagané, 84 (1998), 333

9) E. M. Levin, C. R. Robbins and H. F. McMurdie: Phase Diagrams for Ceramists, Vol. 1, The Am. Ceram. Soc., Columbus, Ohio, (1964), 204.

10) Slag Atlas, 2nd Ed., Verein Deutscher Eisenhuttenleute (VDEh), Verlag Stahleisen GmbH, Düsseldorf, (1995), 379

11) M. Hirasawa, K. Mori, M. Sano, A. Honaka, Y. Shimatani and Y. 
Okazaki: Tetsu-to-Hagané, 73 (1987), 1343.

12) T. Hirata, M. Ishikawa and S. Anezaki: ISIJ Int., 32 (1992), 182.

13) S. Ban-Ya: ISIJ Int., 33 (1993), 2.

14) K. Mori and M. Sano: Tetsu-to-Hagané, 67 (1981), 207.

\section{Appendix}

\section{Calculation Method of $\boldsymbol{\gamma}_{\mathrm{SiO}_{2}}$.}

By using interaction energy of cation, ${ }^{13)} \gamma_{\mathrm{SiO}_{2}[\text { R.S.] }}$ was calculated by Eq. (A-1). In this equation, $\mathrm{SiO}_{2}$ (R.S.) means regular solution of $\mathrm{SiO}_{2}$.

$$
\begin{aligned}
R T & \ln \gamma_{\mathrm{SiO}_{2}(\mathrm{R} . \mathrm{S} .)}=-41840 X_{\mathrm{FeO}}^{2}+32640 X_{\mathrm{FeO}}^{2}-75310 X_{\mathrm{MnO}}^{2} \\
& -133890 X_{\mathrm{CaO}}^{2}-66940 X_{\mathrm{MgO}}^{2}+9460 X_{\mathrm{FeO}} X_{\mathrm{FeO}}{ }_{1.5} \\
& -124260 X_{\mathrm{FeO}} X_{\mathrm{MnO}}-144350 X_{\mathrm{FeO}} X_{\mathrm{CaO}}-142250 X_{\mathrm{FeO}} X_{\mathrm{MgO}} \\
& +131810 X_{\mathrm{FeO}_{1.5}} X_{\mathrm{MnO}}-5440 X_{\mathrm{FeO}_{1.5}} X_{\mathrm{CaO}} \\
& -31370 X_{\mathrm{FeO}_{1.5}} X_{\mathrm{MgO}}-117150 X_{\mathrm{MnO}} X_{\mathrm{CaO}}
\end{aligned}
$$

$$
-204170 X_{\mathrm{MnO}} X_{\mathrm{MgO}}-100410 X_{\mathrm{CaO}} X_{\mathrm{MgO}}
$$

where, $X$ : mole fraction $(-)$.

2. Calculation Method of Agitation Energy ${ }^{14)}$

$$
\varepsilon=6.18 V_{\mathrm{g}} T\left\{\ln \left(1+\frac{\rho_{\mathrm{m}} g H}{P_{\mathrm{a}}}\right)+\eta\left(1+\frac{T_{\mathrm{a}}}{T}\right)\right\} \ldots(\mathrm{A}-2)
$$

where,

$\varepsilon: \quad$ agitation energy $(\mathrm{J} / \mathrm{s})$

$V_{\mathrm{g}}$ : bottom blowing gas flow rate $\left(\mathrm{Nm}^{3} / \mathrm{min}\right)$

$g$ : acceleration of gravity $\left(\mathrm{m} / \mathrm{s}^{2}\right)$

$H$ : depth of hot metal (m)

$P_{\mathrm{a}}:$ atmospheric pressure $(\mathrm{Pa})$

$\eta$ : energy efficiency of gas expansion by heating (0.06)

$T_{\mathrm{a}}$ : initial temperature of bottom blowing gas (298 K) 